\title{
KEMAMPUAN KOMUNIKASI ANTARPRIBADI MAHASISWA STIKOM MUHAMMADIYAH JAYAPURA ANTARA YANG MENGAKSES TWITTER DAN FACEBOOK (STUDI KOMPARASI)
}

\author{
NURJAYANTI \\ Sekolah Tinggi Ilmu Komunikasi (STIKOM) Muhammadiyah Jayapura \\ Email: nurjayanti.anty@gmail.com
}

\begin{abstract}
This research was conducted to analyze the differences in interpersonal communication skills among college students of STIKOM Muhammadiyah Jayapura between those who access Twitter and Facebook. The type of this research is quantitative research with a positivistic approach. This study uses an explanatory survey method and is a comparative study.The author uses Joseph A. Devito's thoughts about the effectiveness of interpersonal communication. The population in this research were all college students of class 2017, 2018, and 2019 who accessed the Twitter and Facebook as many as 455 people.Determination of the number of samples used according to Arikunto, as much as $20 \%$ of total population, which is as many as 91 people, with a random sampling techniques. Methods of data collection using questionnaires and observations. The results showed that there were differences in the level of interpersonal communication among students college of STIKOM Muhammadiyah Jayapura between those who accessed Twitter and Facebook which were analyzed through parametric analysis ( $t$ test). This means that interpersonal communication in early adulthood is more effective using Facebook than Twitter.
\end{abstract}

Keywords: Interpersonal Communication, Twitter, Facebook, Social Networkin

\begin{abstract}
Abstrak
Penelitian ini dilakukan untuk menganalisis perbedaan keterampilan komunikasi interpersonal di kalangan mahasiswa STIKOM Muhammadiyah Jayapura antara mereka yang mengakses Twitter dan Facebook.Jenis penelitian ini adalah penelitian kuantitatif dengan pendekatan positivistik.Penelitian ini menggunakan metode survei penjelas dan merupakan studi komparatif.Penulis menggunakan pemikiran Joseph A. Devito tentang efektivitas komunikasi antarpribadi.Populasi dalam penelitian ini adalah semua mahasiswa kelas 2017, 2018, dan 2019 yang mengakses Twitter dan Facebook sebanyak 455 orang.Penentuan jumlah sampel yang digunakan menurut Arikunto, sebanyak 20\% dari total populasi, yang adalah sebanyak 91 orang, dengan teknik pengambilan sampel acak.Metode pengumpulan data menggunakan kuesioner dan observasi.Hasil penelitian menunjukkan bahwa terdapat perbedaan tingkat komunikasi interpersonal antara mahasiswa STIKOM Muhammadiyah Jayapura antara mereka yang mengakses Twitter dan Facebook yang dianalisis melalui analisis parametrik (uji t).Ini berarti bahwa komunikasi antarpribadi di awal masa dewasa lebih efektif menggunakan Facebook daripada Twitter.
\end{abstract}

Kata kunci: Komunikasi Interpersonal, Twitter, Facebook, Jejaring Sosial 


\section{PENDAHULUAN}

Hadirnya teknologi baru komunikasi yang juga disebut sebagai media komunikasi dianggap sebagai inovasi baru dalam berkomunikasi. Stewart L. Tubbs dan Sylvia Moss menyatakan bahwa perubahan teknologi terus meningkatkan kecepatan komunikasi secara menakjubkan. Teknologi baru dianggap sebagai “perluasan media". ${ }^{1}$ Dianggap sebagai inovasi baru, karena dalam prosesnya saat ini komunikasi tidak lagi dibatasi oleh jarak, ruang dan waktu. Manusia berkomunikasi di mana saja dan kapan saja.Teknologi baru dijadikan sebagai media komunikasi, memperluas sistem yang sudah ada.Salah satu bukti inovasi dalam berkomunikasi saat ini ialah masyarakat yang telah beralih menggunakan jaringan internet.Jaringan internet memiliki keunggulan yaitu memiliki kecepatan lebih untuk mengirim data.

Werner J. Severin dan rekannya James W. Tankard menegaskan bahwa internet memungkinkan hampir semua orang di belahan dunia mana pun untuk saling berkomunikasi dengan cepat dan mudah. ${ }^{2}$ Internet memudahkan manusia dalam berkomunikasi, sebab internet adalah jaringan yang menghubungkan antara satu komputer dengan komputer lain pada seluruh pengguna di dunia.Hadirnya jaringan internet, mendorong munculnya berbagai jejaring sosial yang cukup digandrungi sebagian besar masyarakat saat ini.Jejaring sosial adalah suatu struktur sosial yang terbentuk dari simpul-simpul (individu atau organisasi) yang dihubungkan atau dipersatukan oleh sebuah situs. ${ }^{3}$ Melalui jejaring sosial inilah, manusia sebagai pengguna bertemu dengan berbagai karakter dan latar belakang yang berbeda dari pengguna lain di seluruh penjuru dunia. Dari sini, pengguna akan menjalin pertemanan dengan pengguna lain di dunia maya (cyberspace).

Jejaring sosial menjadi media baru yang memungkinkan pengguna dari awalnya tidak saling mengenal menjadi saling mengenal.Terlebih pada masyarakat Indonesia yang terdiri atas berbagai suku di penjuru nusantara. Melalui jejaring sosial, manusia tidak hanya bergaul dengan manusia lain dari suku yang sama, melainkan mampu memperluas jaringan pertemanan dengan manusia sebagai pengguna dari suku lain. Cakupan lebih luas yaitu manusia dapat saling mengenal dengan manusia lain dari bangsa atau Negara lain. Bahkan, fenomena yang sering muncul ialah pengguna mengaku bahwa melalui jejaring sosial, jalinan

\section{5.}

${ }^{1}$ Stewart L. Tubbs, Sylvia Moss, Human Communication (Bandung: PT. Remaja Rosdakarya, 2001), h.

${ }^{2}$ Werner J. Severin, James W. Tankard, Jr, Teori Komunikasi : Sejarah, Metode, dan Terapan di Dalam Media Massa (Jakarta: Kencana, 2005), h. 444.

${ }^{3}$ Madcoms, Student Book Series: Mencari Teman Lewat Facebook dan Friendster (Yogyakarta: Andi Offset, 2009), h. 2. 
silaturahmi yang telah lama terputus dapat tersambung kembali.Namun, berbagai pengalaman membuktikan bahwa dari beberapa jejaring sosial tidak semuanya dipahami baik oleh masyarakat.Populernya, masyarakat cenderung memilih dua jejaring sosial sebagai media berkomunikasi mereka.Keduanya adalah situs Twitter dan Facebook. Pada umumnya, komunikasi yang berlangsung dengan menggunakan jejaring sosial termasuk dalam kategori komunikasi antarpribadi, karena penggunaannya melibatkan antara dua atau tiga orang, masing-masing bertindak sebagai pemilik account.

Onong Uchjana Effendy mengemukakan bahwa komunikasi antarpribadi merupakan salah satu bentuk atau tipe komunikasi manusia yang dianggap paling efektif dibanding dengan bentuk atau tipe komunikasi antarmanusia lainnya, di mana komunikasi antarpribadi dinilai paling ampuh dalam kegiatan merubah sikap, kepercayaan, opini, dan perilaku komunikan. ${ }^{4}$ Penggunaan jejaring sosial sebagai media komunikasi antarpribadi ini pun memunculkan berbagai tanggapan. Salah satunya ialah melalui jejaring sosial, komunikasi antarpribadi klasik yakni dengan face to face (tatap muka) kini telah mengalami perkembangan yang sangat signifikan. Hadirnya jejaring sosial, menjadikan seseorang mampu tetap berkomunikasi dengan orang lain tanpa adanya jarak yang menjadi hambatan dalam berkomunikasi, melainkan menjadikan komputer sebagai mediator atau yang lebih dikenal dengan perspektif CMC (Computer-mediated communication).

Terdapat beberapa karakteristik efektivitas komunikasi antarpribadi oleh Joseph A. DeVito yang dapat digunakan dalam mengukur kemampuan komunikasi antarpribadi seseorang. Kaitan antara penggunaan karakteristik efektivitas komunikasi dalam mengukur kemampuan komunikasi antarpribadi terletak pada gagasan Joseph A. DeVito yang mengemukakan bahwa karakteristik efektivitas komunikasi antarpribadi bertujuan memberikan pandangan tentang perilaku yang sebaiknya dipilih bagi para pelaku komunikasi antarpribadi dalam menghadapi berbagai situasi komunikasi demi mewujudkan komunikasi yang efektif. Kemampuan komunikasi antarpribadi diartikan sebagai kecakapan atau kesanggupan seseorang dalam menciptakan suasana komunikasi yang lebih akrab, salah satunya dengan menentukan perilaku yang sebaiknya dipilih seseorang dalam mewujudkan suasana komunikatif tersebut.Karakteristik efektivitas komunikasi antarpribadi oleh Joseph A. DeVito, dilihat dari dua perspektif, yaitu: (1) Perspektif Humanistik, meliputi: keterbukaan, empati, sikap mendukung, sikap positif, kesetaraan. (2) Perspektif Pragmatis, meliputi: kepercayaan diri, kebersatuan, manajemen interaksi, daya pengungkapan, orientasi

${ }^{4}$ Onong Uchjana Effendy, Dinamika Komunikasi (Bandung : PT. Remaja Rosdakarya, 2003), h. 61. 
ke pihak lain. Karakteristik efektivitas komunikasi antarpribadi di atas, tidak hanya dapat diterapkan ketika proses komunikasi berlangsung pada kehidupan nyata, tapi juga dapat diterapkan dalam proses komunikasi yang berlangsung di dunia maya. Fitur yang terdapat pada situs Twitter dan Facebook mampu mendukung penerapan karakteristik tersebut.Dari hasil survei penggunaan jejaring sosial Twitter dan Facebook dinyatakan bahwa pengguna terbanyak berasal dari usia remaja dan usia dewasa awal. Pada sebuah tulisan di Kompasiana.com, menyebutkan bahwa pengguna Twitter pada usia 15-24 tahun mendominasi hingga 66\%, sedangkan pengguna dengan usia 25-44 tahun hanya sebesar $29 \%$. Kemudian, disebutkan bahwa pengguna Facebook terbanyak di Indonesia berusia 16-24 tahun yakni $67,9 \%$, sedangkan pengguna dengan usia 25-44 tahun hanya sebesar $28 \% .{ }^{5}$ Dari data hasil survei tersebut, penulis menjadikan kalangan usia dewasa awal yang merupakan mahasiswa tiga angkatan terakhir (2017, 2018, dan 2019) STIKOM Muhammadiyah Jayapura sebagai sampel penelitian. Hal ini juga berdasar atas pengidentifikasian yang telah dilakukan penulis sebelum penentuan lokasi penelitian.Dari pengidentifikasian awal tersebut, penulis menemukan bahwa memang banyak mahasiswa STIKOM Muhammadiyah Jayapura yang mengaksesTwitter dan Facebook. Berdasarkan uraian tersebut, maka penulis mengidentifikasi bahwa pentingnya penelitian ini dilakukan yaitu untuk menguji perbedaan tingkat kemampuan komunikasi antarpribadi mahasiswa STIKOM Muhammadiyah Jayapura antara yang mengakses situs Twitter danFacebook.

\section{METODE PENELITIAN}

Penelitian ini dilaksanakan di kampus Sekolah Tinggi Ilmu Komunikasi (STIKOM) Muhammadiyah Jayapura, Distrik Abepura, Kota Jayapura, Provinsi Papua. Populasi dalam penelitian ini adalah seluruh mahasiswa angkatan 2017, 2018, dan 2019 yang berstatus aktif dan tercatat memiliki akun Twitter dan Facebook sebanyak 455 orang. Mahasiswa yang hanya memiliki akun pada satu jejaring sosial saja, tidak dimasukkan dalam populasi. Selanjutnya, penentuan jumlah sampel yang digunakan peneliti berdasar pada pendapat Suharsimi Arikunto, bahwa jumlah sampel dapat diambil tergantung dari kemampuan peneliti yang dilihat dari waktu, tenaga, dan dana. Jumlah populasi yang lebih dari 100, maka jumlah sampel dapat dibatasi 10-15\% atau 20-25\%. ${ }^{6}$ Sehingga, jumlah sampel yang akan digunakan

5"PKS Menapak 2 Besar ?”, Situs Resmi Politik Kompasiana: http://politik.kompasiana.com/2013/04/29/pks-menapak-2-besar--551252.html (diakses pada tanggal 20 Oktober 2013).

${ }^{6}$ Suharsimi Arikunto, Prosedur Penelitian Suatu Pendekatan Praktik, Edisi Revisi VI, (Jakarta: Rineka Cipta, 2006), h. 134. 
ialah 20\% dari 455 orang yaitu 91 orang mahasiswa. Untuk pembagian distribusi setiap angkatan, penulis menggunakan teknik Random Sampling dengan tujuan mempermudah pendistribusian dan untuk memberikan peluang yang sama bagi setiap mahasiswa yang memenuhi kriteria.

Metode pengumpulan data yang digunakan dalam penelitian ini adalah kuesioner berupa kuesioner tertutup yang akan diberikan kepada responden untuk mengukur tingkat kemampuan komunikasi antarpribadi mahasiswa dalam menggunakan Twitter dan Facebook. Metode pengumpulan data lain yang digunakan adalah observasi yang dilakukan dengan cara mengamati dan mencatat secara sitematik gejala-gejala yang diselidiki untuk mendapatkan data mengenai kondisi mahasiswa STIKOM Muhammadiyah Jayapura dalam mengakses Twitter dan Facebook.

Terhadap variabel penelitian dilakukan analisis deskriptif dan parametrik. Analisis deskriptif digunakan untuk menjelaskan kemampuan komunikasi antarpribadi mahasiswa STIKOM Muhammadiyah Jayapura yang mengakses Twitter dan Facebook. Sedangkan analisuis parametrik dengan menggunakan uji $\mathrm{T}$ digunakan untuk membedakan tingkat kemampuan komunikasi antarpribadi mahasiswa antara yang mengakses Twitter dan Facebook.

\section{HASIL PENELITIAN}

Indikator yang digunakan dalam mengukur tingkat kemampuan komunikasi antarpribadi pengguna Twitter dan Facebook ialah berdasar pada perspektif humanistik dan pragmatis dalam konsep karakteristik efektifitas komunikasi antarpribadi yang dikemukakan oleh Joseph A. Devito. Indikator tersebut adalah keterbukaan, empati, sikap mendukung, sikap positif, kesetaraan, kepercayaan diri, kebersatuan, manajemen interaksi, daya pengungkapan, dan orientasi ke pihak lain. 


\section{Tingkat Kemampuan Komunikasi Antarpribadi Mahasiwa STIKOM Muhammadiyah Jayapura yang Mengakses Twitter}

Tabel 1

Distribusi frekuensi tanggapan responden terhadap kemampuan komunikasi antarpribadimahasiswa STIKOM Muhammadiyah Jayapura yang mengakses situs Twitter

\begin{tabular}{|c|c|c|c|}
\hline No & Persentase (\%) & Kategori & Frekuensi \\
\hline 1. & $0 \%-20 \%$ & Sangat tidak baik & 0 \\
\hline 2. & $21 \%-40 \%$ & Tidak baik & 0 \\
\hline 3. & $41 \%-60 \%$ & Kurang baik & 13 \\
\hline 4. & $61 \%-80 \%$ & Baik & 7 \\
\hline 5. & $81 \%-100 \%$ & Sangat baik & 0 \\
\hline \multicolumn{3}{|c|}{ Jumlah } & 20 \\
\hline
\end{tabular}

Sumber: Hasil olahan data (2019)

Dari tabel 1 di atas, menunjukkan bahwa frekuensi tertinggi terdapat pada kategori kurang baik, dengan jumlah frekuensi pertanyaan sebesar 13 dari 20 pertanyaan yang ada. Sedangkan, sisanya berada pada kategori baik dengan frekuensi pertanyaan sebesar 7 pertanyaan. Maka, dapat diartikan bahwa tingkat kemampuan komunikasi antarpribadi mahasiswa STIKOM Muhammadiyah Jayapura yang mengakses Twitter dinyatakan kurang baik. Pada indikator keterbukaan, responden dalam mengungkapkan/mempublikasikan identitas diri berada pada kategori kurang baik. Selanjutnya, responden dalam mengaktifkan fitur penanda lokasi juga berada pada kategori kurang baik. Pada indikator empati, responden dalam berempati terhadap perasaan senang dan sedih orang lain berada pada kategori kurang baik. Pada indikator sikap mendukung, responden dalam menggunakan fitur retweet/favorit/like/share berada pada kategori kurang baik. Selanjutnya, responden dalam menyatakan persetujuan terhadap pesan orang lain juga berada pada kategori yang kurang baik. Pada indikator sikap positif, responden dalam bersikap positif ketika berkomentar dan menanggapi komentar berada pada kategori baik. Pada indikator kesetaraan, responden dalam berinteraksi dengan orang yang berstatus sosial lebih rendah dan lebih tinggi berada pada kategori kurang baik. Pada indikator kepercayaan diri, responden dalam mengawali percakapan dan terlibat percakapan panjang berada pada kategori kurang baik. Pada indikator kebersatuan, responden dalam menggunakan bahasa/simbol yang dimengerti oleh orang lain berada pada kategori baik, dan responden dalam memahami bahasa/simbol yang digunakan oleh orang lain berada pada kategori kurang baik. Pada indikator manajemen interaksi, responden dalam menanggapi pesan orang lain berada pada kategori baik, dan responden dalam melakukan followback/konfirmasi pertemanan berada pada kategori kurang baik. Pada indikator daya pengungkapan, responden dalam mengungkapkan pikiran/perasaan berada 
pada kategori kurang baik, dan responden dalam menggunakan smiley berada pada kategori baik. Pada indikator orientasi ke pihak lain, responden dalam menunjukkan perhatian/minat terhadap pengungkapan diri orang lain berada pada kategori kurang baik dan responden dalam menerima pendapat orang lain berada pada kategori baik.

\section{Tingkat Kemampuan Komunikasi Antarpribadi Mahasiwa STIKOM Muhammadiyah Jayapura yang Mengakses Facebook}

Tabel 2

Distribusi frekuensi tanggapan responden terhadap kemampuan komunikasi antarpribadimahasiswa STIKOM Muhammadiyah Jayapura yang mengakses Facebook

\begin{tabular}{|c|c|c|c|}
\hline No & Persentase (\%) & Kategori & Frekuensi \\
\hline 1. & $0 \%-20 \%$ & Sangat tidak baik & 0 \\
\hline 2. & $21 \%-40 \%$ & Tidak baik & 0 \\
\hline 3. & $41 \%-60 \%$ & Kurang baik & 0 \\
\hline 4. & $61 \%-80 \%$ & Baik & 19 \\
\hline 5. & $81 \%-100 \%$ & Sangat baik & 1 \\
\hline \multicolumn{3}{|c|}{ Jumlah } \\
\hline
\end{tabular}

Sumber: Hasil olahan data (2019)

Dari tabel 2 di atas, menunjukkan bahwa frekuensi tertinggi terdapat pada kategori baik, dengan jumlah frekuensi pertanyaan sebesar 19 dari 20 pertanyaan yang ada. Maka, dapat diartikan bahwa tingkat kemampuan komunikasi antarpribadi mahasiswa STIKOM Muhammadiyah Jayapura yang mengakses Facebook dinyatakan baik. Pada indikator keterbukaan, responden dalam mengungkapkan/mempublikasikan identitas diri berada pada kategori sangat baik. Selanjutnya, responden dalam mengaktifkan fitur penanda lokasi berada pada kategori baik. Pada indikator empati, responden dalam berempati terhadap perasaan senang dan sedih orang lain berada pada kategori baik. Pada indikator sikap mendukung, responden dalam menggunakan fitur like/share berada pada kategori baik. Selanjutnya, responden dalam menyatakan persetujuan terhadap pesan orang lain juga berada pada kategoribaik. Pada indikator sikap positif, responden dalam bersikap positif ketika berkomentar dan menanggapi komentar berada pada kategori baik. Pada indikator kesetaraan, responden dalam berinteraksi dengan orang yang berstatus sosial lebih rendah dan lebih tinggi berada pada kategori baik. Pada indikator kepercayaan diri, responden dalam mengawali percakapan dan terlibat percakapan panjang berada pada kategori baik. Pada indikator kebersatuan, responden dalam menggunakan bahasa/simbol yang dimengerti oleh orang lain berada pada kategori baik, dan responden dalam memahami bahasa/simbol yang digunakan oleh orang lain juga berada pada kategori baik. Pada indikator manajemen 
interaksi, responden dalam menanggapi pesan orang lain berada pada kategori baik, dan responden dalam melakukan konfirmasi pertemanan juga berada pada kategori baik. Pada indikator daya pengungkapan, responden dalam mengungkapkan pikiran/perasaan berada pada kategori baik, dan responden dalam menggunakan smileyjuga berada pada kategori baik. Pada indikator orientasi ke pihak lain, responden dalam menunjukkan perhatian/minat terhadap pengungkapan diri orang lain berada pada kategori baik dan responden dalam menerima pendapat orang lain juga berada pada kategori baik.

\section{Tingkat Kemampuan Komunikasi Antarpribadi Mahasiswa STIKOM Muhammadiyah Jayapura antara yang Mengakses Twitter dan Facebook.}

Berdasarkan hasil perhitungan dengan menggunakan bantuan program SPSS versi 20, diperoleh nilai t hitung sebesar 24,370 dengan signifikansi 0,000. Berdasarkan kriteria pengujian yang berlaku pada uji $t$, nilai $t$ hitung $=24,370>t$ tabel $=1,987$ atau nilai sig $(2$ tailed) $=0,000<0,05(5 \%)$, maka $\mathrm{H}_{0}$ ditolak dan $\mathrm{H}_{1}$ diterima yang berarti bahwa terdapat perbedaan tingkat kemampuan komunikasi antarpribadi mahasiswa STIKOM Muhammadiyah Jayapura antara yang mengakses Twitter dan Facebook. Bila hipotesis ini diinterpretasikan dan digabungkan dengan hasil analisis deskriptif sebelumnya, maka dapat disimpulkan bahwa kemampuan komunikasi antarpribadi mahasiswa STIKOM Muhammadiyah Jayapura yang mengakses Facebook lebih tinggi dibandingkan dengan mahasiswa STIKOM Muhammadiyah Jayapura yang mengakses situs Twitter. Perbedaan tersebut dapat dilihat dari adanya perbedaan jumlah frekuensi tertinggi pada masing-masing tabel distribusi frekuensi tanggapan responden terhadap kemampuan komunikasi antarpribadi.Pada tabel 1 menunjukkan frekuensi tertinggi berada pada kategori kurang baik.Artinya, tingkat kemampuan komunikasi antarpribadi mahasiswa STIKOM Muhammadiyah Jayapura yang mengakses Twitter dinyatakan kurang baik.Sedangkan, pada table 2 menunjukkan frekuensi tertinggi berada pada kategori baik.Artinya, tingkat kemampuan komunikasi antarpribadi mahasiswa STIKOM Muhammadiyah Jayapura yang mengakses situs Facebook dinyatakan baik.

\section{PEMBAHASAN}

Tingkat kemampuan komunikasi antarpribadi mahasiswa sangat ditentukan oleh kemampuannya dalam mengaplikasikan ancangan efektivitas komunikasi antarpribadi yang berdampak pada terciptanya keharmonisan antara satu orang dengan orang lain yang menjadi rekan komunikasinya di Twitter dan Facebook.Jika hasil analisis komparatif dijabarkan 
dalam ancangan efektivitas komunikasi antarpribadi berdasarkan dua perspektif (Humanistik dan Pragmatis) yang dikemukakan oleh Joseph A. DeVito, maka akan dibahas sebagai berikut:

\section{1) Keterbukaan (openness)}

Kemampuan mahasiswa dalam mengungkapkan/mempublikasikan identitas diri pada Facebook lebih baik daripada di Twitter. Salah satu faktor penyebabnya adalah pengguna Twitter yang cenderung heterogen (mayoritas berasal dari luar lingkungan) dibanding Facebook yang penggunanya cenderung memberi saran pertemanan yang berada dalam lingkungan pengguna. Sifat yang heterogen ini menandakan bahwa pengguna berasal dari latar belakang yang berbeda yang kemudian membuat mahasiswa merasa tidak nyaman jika orang lain yang sama sekali tidak dikenalnya menjadi tahu tentang identitas dirinya. Selain itu, orang lain akan lebih mudah menelusuri identitas tersebut.

\section{2) Empati (empathy)}

Sikap empati mahasiswa terhadap perasaan senang orang lain pada Facebook lebih baik daripada di Twitter. Hal tersebut dapat dilihat dari faktor ketertarikan mahasiswa yang lebih cenderung senang mengakses Facebook. Di Facebook, mahasiswa lebih banyak menemui pesan dari teman-teman yang sering menjadi lawannya berinteraksi dalam kehidupan nyata. Dengan begitu, setiap pesan yang ditemuinya di Facebook lebih menarik minatnya untuk bersikap empati.

3) Sikap Mendukung (supportiveness)

Sikap mendukung mahasiswa yang terwujud melalui penggunaan fitur like/share di Facebook lebih baik daripada sikap mendukung mahasiswa di Twitter yang terwujud melalui fitur retweet/favorit. Selain itusikap mendukung yang terwujud melalui pernyataan secara langsung terhadap pesan orang lain di Facebook yang lebih baik dibanding di Twitter.

\section{4) Sikap Positif (positiveness)}

Sikap positif mahasiswa yang terwujud dalam pengiriman komentar terhadap pesan orang lain di Facebook sama baiknya dengan di Twitter. Hal ini dapat disebabkan karena mahasiswa menyadari bahwa dalam memberikan komentar, sikap positif harus selalu diutamakan. Begitupun sebaliknya, sikap positif mampu ditunjukkan ketika menanggapi komentar dari orang lain.

5) Kesetaraan (equality)

Sikap mengedepankan kesetaraan mahasiswa terwujud melalui interaksi yang dilakukan terhadap orang yang memiliki status sosial lebih rendah dan lebih tinggi di Facebook lebih baik dibanding di Twitter. Hal tersebut disebabkan karena mahasiswa 
mengaku sulit mengidentifikasi status sosial orang lain yang ditemuinya di Twitter. Sejalan dengan kurangnya keterbukaan (openness) seseorang dalam mencantumkan identitas diri pada profilnya. Kurangnya keterbukaan tersebut membuat orang lain sulit mengidentifikasi status sosial melalui Twitter.

\section{6) Kepercayaan Diri (confidence)}

Kepercayaan diri mahasiswa yang terwujud melalui kemampuan mengawali percakapan dengan orang lain di Facebook lebih baik dibanding di Twitter. Hal ini disebabkan karena lingkar pertemanan di Facebook yang mayoritas berasal dari lingkungannya sendiri, seperti teman-teman kampus, dosen, dan teman-teman organisasinya dibanding di Twitter yang penggunanya berada di luar lingkar pertemanannya sehari-hari dalam dunia nyata.

\section{7) Kebersatuan (immediacy)}

Sikap kebersatuan mahasiswa yang terwujud melalui bahasa/simbol yang digunakan dapat dimengerti oleh orang lain di Facebook sama baiknya dengan di Twitter. Namun, di sisi lain, sikap kebersatuan yang terwujud melalui pemahaman terhadap bahasa/simbol yang digunakan oleh orang lain lebih baik di Facebook daripada di Twitter. Hal ini tidak berarti bahwa mahasiswa sama sekali tidak memahami bahasa/simbol dari orang lain, namun kurangnya pemahaman mahasiswa ini dapat disebabkan karena rendahnya antusiasme mahasiswa dalam menggunakan Twitter sebagai media komunikasi. Rendahnya antusiasme dapat berarti bahwa mahasiswa cenderung acuh atau mengabaikan pesan orang lain yang mengandung simbol/bahasa pada Twitter.

8) Manajemen Interaksi (interaction management)

Manajemen interaksi mahasiswa yang terwujud melalui fitur followback pada Twitter dan Konfirmasi Pertemanan pada Facebook menunjukkan hasil yang lebih baik diterapkan mahasiswa di Facebook dibanding di Twitter. Hal ini dapat disebabkan karena pada aplikasi Facebook terdapat sistem yang otomatis memberi saran pertemanan yang berasal dari teman yang sudah ada dalam daftar pertemanan seorang pengguna.

9) Daya Pengungkapan (expresiveness)

Daya pengungkapan mahasiswa yang diwujudkan melalui pengungkapan pikiran/perasaan di Facebook lebih baik dibanding di Twitter. Hal ini disebabkan karena orang-orang yang sering ditemui mahasiswa di Facebook merupakan orang-orang yang berasal dari kalangan usia dewasa awal yang memiliki orientasi pikiran/perasaan yang cenderung sama. Dengan begitu, mahasiswa merasa lebih nyaman mengungkapkan pikiran/perasaannya di Facebook. 


\section{0) Orientasi Ke Pihak Lain (other orientation)}

Orientasi mahasiswa ke pihak lain terwujud melalui perhatian/minat terhadap pengungkapan diri dari orang lain di Facebook lebih baik daripada di Twitter. Hal ini disebabkan karena pada dasarnya mahasiswa jarang menggunakan Twitter untuk berinteraksi dengan orang lain. Sehingga, wajar jika mahasiswa mengatakan jarang memberikan perhatian/minat terhadap pengungkapan diri dari orang lain. Pengungkapan diri yang dimaksud adalah penyampaian tentang hal-hal yang berkaitan dengan identitas maupun gagasan seseorang kepada orang lain. Dengan kata lain, mahasiswa menganggap bahwa di Twitter mereka tidak menemukan dunianya. Twitter dianalogikan dunia asing bagi mahasiswa dibandingkan Facebook yang membuatnya tetap terhubung secara virtual dengan rekan-rekannya yang sering ditemui dalam kehidupan sehari-hari.

Hal yang paling menonjol yang ditemui peneliti pada analisis deskriptif terhadap kemampuan komunikasi antarpribadi mahasiswa dalam mengakses Facebook terletak pada ancangan keterbukaan (openness), bahwa sebagian besar mahasiswa sangat mampu bersikap terbuka ketika mencantumkan identitas dirinya pada halaman profil masingmasing.Keterbukaan menjadi salah satu faktor penentu berlanjutnya suasana komunikasi.Sebab, sikap keterbukaan dianggap menjadi awal dari sebuah komunikasi, di mana pelaku dapat saling mengenal melalui adanya sikap tersebut. Tidak hanya fokus pada ancangan tersebut, ancangan lain juga menjadi faktor penentu terciptanya hubungan yang harmonis. Berdasarkan hasil analisis, jika dikaitkan dengan tujuan dan kegunaan penelitian ini, maka dapat dinyatakan bahwa media sosial Facebook baik dijadikan sebagai salah satu media komunikasi dan penyebaran informasi bagi pihak kampus pada khususnya. Selanjutnya, rendahnya tingkat kemampuan komunikasi antarpribadi mahasiswa dalam menggunakan Twitter dapat diinterpretasikan bahwa minat mahasiswa dalam mengakses Twitter juga rendah.Berdasarkan hasil analisis, jika dikaitkan dengan tujuan dan kegunaan penelitian ini, maka dapat dinyatakan bahwa jejaring sosial Twitter kurang baik dijadikan salah satu media komunikasi dan penyebaran informasi bagi pihak kampus pada khususnya.

Cara berkomunikasi yang semakin berkembang seiring dengan perkembangan teknologi, menjadi salah satu hal yang penting untuk dipahami demi tercapainya tujuan komunikasi. Dengan harapan bahwa cara berkomunikasi yang baru dengan berbagai teknologinya lebih membantu manusia dalam menciptakan komunikasi yang efektif. Sama halnya dengan penelitian ini yang berfokus pada masyarakat usia dewasa awal yaitu mahasiswa STIKOM Muhammadiyah Jayapura yang berusia 19-24 tahun yang menjadi 
target utama dari pihak pencipta cara baru berkomunikasi. Dalam hal ini ialah komunikasi yang dilakukan melalui dua jejaring sosial yang paling popular, yaitu Twitter dan Facebook.

\section{PENUTUP/SIMPULAN}

Kemampuan komunikasi antarpribadi mahasiswa STIKOM Muhammadiyah Jayapura yang mengakses situs Facebook berada dalam kategori baik.Hal ini sangat ditentukan oleh baiknya kemampuan siswa-siswi dalam menerapkan ancangan efektivitas komunikasi antarpribadi demi terwujudnya komunikasi yang efektif serta terciptanya hubungan yang lebih akrab.Kemampuan komunikasi antarpribadi mahasiswa STIKOM Muhammadiyah Jayapura yang mengakses situs Twitter berada dalam kategori kurang baik.Hal ini disebabkan oleh kurang baiknya kemampuan siswa-siswi dalam menerapkan ancangan efektivitas komunikasi antarpribadi. Sehingga, dapat disimpulkan bahwa komunikasi mahasiswa dengan orang lain pada situs Twitter kurang efektif dan kurang akrab. Berdasarkan hasil perhitungan Uji $\mathrm{T}$ diperoleh nilai t hitung yang lebih besar dari t tabel dan nilai sig(2-tailed) yang lebih kecil dari 0,05 (5\%), maka dapat disimpulkan bahwa terdapat perbedaan tingkat kemampuan komunikasi antarpribadi mahasiswa STIKOM Muhammadiyah Jayapura antara yang mengakses situs Twitter dan Facebook.

Penelitian ini telah menunjukkan bahwa ancangan efektivitas komunikasi antarpribadi oleh Joseph A. DeVito penting diterapkan dalam berbagai situasi komunikasi, termasuk komunikasi yang menggunakan jejaring sosial yang hanya berlangsung di dunia maya.Dengan demikian, bahwa penerapan ancangan efektivitas komunikasi antarpribadi dalam berbagai situasi komunikasi menjadi komponen utama dalam terwujudnya komunikasi yang efektif sekaligus mampu menciptakan hubungan yang lebih akrab serta harmonis.Implikasi penelitian ini ialah terhadap penerapan ancangan komunikasi antarpribadi dalam penggunaan jejaring sosial sebagai media komunikasi, implikasi terhadap upaya untuk meningkatkan kesadaran para pengguna dalam memanfaatkan jejaring sosial ke arah yang lebih positif sebagai media komunikasi antarpribadi, serta implikasi terhadap pihak kampus untuk memberikan arahan dan bimbingan kepada para mahasiswa agar tidak menyalah gunakan berbagai teknologi yang ada saat ini, juga memberikan informasi bagi pihak terkait baik bagi orang tua maupun lingkungan sekitarnya tentang penggunaan jejaring sosial yang efektif untuk membangun komunikasi kepada mahasiswa yang tidak membuatnya merasa diawasi. Namun, lebih fokus terhadap terciptanya keakraban hubungan yang wajar layaknya teman di dunia nyata. 
Melalui penerapan ancangan efektivitas komunikasi antarpribadi pada situs Twitter dan Facebook, potensi tercapainya tujuan komunikasi itu sendiri akan semakin besar. Dengan begitu, dapat pula dikatakan bahwa penelitian ini berimplikasi terhadap kemampuan seseorang dalam mengenal dirinya sendiri maupun orang lain, mengetahui dunia luar, menciptakan dan memelihara hubungan yang bermakna, mengubah sikap dan perilaku, bermain dan mencari hiburan serta sebagai ajang untuk membantu tenaga-tenaga ahli dalam menjalankan profesinya. Dengan begitu, pemanfaatan terhadap inovasi berkomunikasi ini dapat semakin terarah dan bermanfaat.Hal ini sesuai dengan tujuan komunikasi antarpribadi itu sendiri.Berbagai kenyataan yang ditemukan peneliti di lapangan, peneliti menyarankan kepada para pengguna bahwa peran orang tua serta para pembimbing baik di lingkungan pendidikan formal maupun non formal merupakan hal yang penting.Para pengguna seharusnya menyadari bahwa pengawasan yang dilakukan pihak terkait tersebut, merupakan hal yang wajar dan suatu keharusan. Sebab, pengawasan merupakan salah satu pencegahan atas berbagai kondisi yang tidak diharapkan terjadi, seperti maraknya kasus kejahatan dunia maya yang kebanyakan menimpa kalangan remaja dan usia dewasa awal yang dilakukan oleh pihak yang tidak bertanggung jawab.

\section{DAFTAR PUSTAKA}

Alang, M. Sattu, dkk. (2007).Pengantar Ilmu Komunikasi. Makassar: Alauddin Press.

Arikunto, Suharsimi. (2006).Prosedur Penelitian Suatu Pendekatan Praktik, Edisi Revisi VI; Jakarta: Rineka Cipta.

Budyatna, Muhammad dan Leila Mona Ganiem.(2011). Teori Komunikasi Antarpribadi. Jakarta: Kencana.

Departemen Pendidikan dan Kebudayaan. (2001).Kamus Besar Bahasa Indonesia. Jakarta: Balai Pustaka.

DeVito, Joseph A. (1997).Human Communication.Terj. Agus Maulana MSM, Komunikasi Antarmanusia: Kuliah Dasar, Edisi Kelima. Jakarta: Proffesional Books.

Effendy, Onong Uchjana. (2003). Dinamika Komunikasi. Bandung: PT. Remaja Rosdakarya.

Faisal, Sanapiah. (2007).Format-format Penelitian Sosial, Dasar-dasar dan Aplikasi, Cetakan VIII; Jakarta: PT. RajaGrafindo Persada.

Ghozali, Imam. (2005). Aplikasi Analisis Multivariat dengan Program SPSS. Semarang: UNDIP.

Holmes, David. (2012). Communication Theory: Media, Technology, and Society. Terj. Teguh Wahyu Utomo, Teori Komunikasi: Media, Teknologi, dan Masyarakat. Yogyakarta: Pustaka Pelajar. 
J.Severin, Werner dan James W. Tankard. (2005).Teori Komunikasi: Sejarah, Metode, dan Terapan di Dalam Media Massa. Jakarta: Kencana.

Kriyantono, Rachmat. (2010). Teknik Praktis Riset Komunikasi: Disertai Contoh Praktis Riset Media, Public Relations, Advertising, Komunikasi Organisasi, Komunikasi Pemasaran. Jakarta: Kencana Prenada Media Group.

L.Tubbs, Stewart dan Sylvia Moss. (2001).Human Communication. Bandung: PT. Remaja Rosdakarya.

Madcoms. (2009).Student Book Series: Mencari Teman Lewat Facebook dan Friendster. Yogyakarta: Andi Offset.

Mulyana, Deddy. (2000). Ilmu Komunikasi: Suatu Pengantar. Bandung: PT. Remaja Rosdakarya.

Rohman, Abd. (2007). Komunikasi dalam Al-Qur'an: Relasi Ilahiyah dan Insaniyah. Malang: UIN Malang Press.

Senianti, Endang. (2011) "Efektivitas Penggunaan Facebook Sebagai Media Komunikasi Antarpribadi Siswa SMA Negeri 1 Makassar". Skripsi.Makassar.Fakultas Dakwah dan Komunikasi UIN Alauddin Makassar.

Singgih, Santoso. (2000)SPSS Mengolah Data Statistik Secara Professional. Jakarta: Media Komputindo.

Soetjiningsih. (2004).Tumbuh Kembang Remaja dan Permasalahannya. Jakarta: CV Sagung Seto.

Syekh, Sayid. (2011).Pengantar Statistik Ekonomi dan Sosial. Jakarta: Gaung Persada Press.

Yatiningsih, Fuji. (2013).Step by Step Belajar Komputer dan Internet Untuk Pemula. Yogyakarta: Buku Pintar.

\section{Media Online}

"Facebook".Wikipedia Bahasa Indonesia, Ensiklopedia Bebas. http://id.wikipedia.org/wiki/Facebook (Diakses pada tanggal 6 Desember 2013).

"Menguji Kualitas Instrumen Penelitian", Situs Panduan Skripsi. http://panduanskripsi.com/menguji-kualitas-instrumen-penelitian/ (Diakses pada tanggal 6 Januari 2014).

"Para Remaja Kini Mulai Tinggalkan Facebook, Beralih ke Instagram, Twitter serta WhatsApp".Situs Berita Teknologi.com.http://www.beritateknologi.com/para-remajakini-mulai-tinggalkan-facebook-beralih-ke-instagram-twitter-serta-whatsapp/ (Diakses pada tanggal 14 Februari 2014).

"PKS Menapak 2 Besar".Situs Resmi Politik Kompasiana.http://politik.kompasiana.com/2013/04/29/pks-menapak-2-besar-551252.html(diakses pada tanggal 20 Oktober 2013).

Burhan, Nasrianti. "Pengertian Kemampuan". Blog My Adventure.http://nasriantiburhan.blogspot.com/2013/01/pengertian-kemampuan.html (Diakses pada tanggal 21 Desember 2013). 
Echaressa.Tugas Akhir Teknologi Komunikasi, Blog Hi I'm Echa. http://ressarizkia.blogpsot.com/2010/06/tugas-akhir-teknologi-komunikasi 12.html (Diakses pada tanggal 20 Oktober 2013). 